\title{
IAMJ
}

INTERNATIONAL

AYURVEDIC

MEDICAL JOURNAL

\section{EFFICACY OF YOGAABHYAS IN THE MANGEMENT OF MADHUMEHA W.S.R TO NIDDM (TYPE 2)}

\section{Bansode Sheetal}

Assistant Professor, Swasthavritta Dept, Shri dhanwanteri PG Ayurved Medical College Hospital and Research Centre, Semri, Mathura, Uttar Pradesh, India

Corresponding Author: sheetalbansode8040@gmail.com

https://doi.org/10.46607/iamj.3809012021

(Published online: January 2021)

Open Access

(C) International Ayurvedic Medical Journal, India 2021

Article Received: 30/12/2020 - Peer Reviewed: 02/01/2021 - Accepted for Publication: 04/01/2021

Check for updates

\begin{abstract}
Ayurveda is the science of living being. It begins with right lifestyle including daily and seasonal health regime designed for each individual based upon their nature, constitution, environment and life circumstances. Madhumeha is the subtype of Prameha. Due to resemblance of the feature of Madhumeha with that of DM explained in modern medicine, it is correlated with DM. According to WHO approximately 220 million people worldwide have type 2 diabetes mellitus. It is widely recognized that stress may have negative effects on health and that patients with type 2 diabetes may be at an increased risk. Yoga is an ancient Indian psychological and physical exercise regime and a number of controlled studies exist on the effectiveness of yoga on diabetes mellitus. Yogic practices strengthen and increase the tone of weak muscles and help with conscious control over autonomic function of the body. So, the present study on the role of Yogaabhyas as a lifestyle modification in Madhumeha.
\end{abstract}

Keywords: Madhumeha, type 2 diabetes, asana in diabetes

\section{INTRODUCTION}

"Swasthasya Swathya Rakshanam Athurasya Vyadhi Parimokshanam". The aim of traditional medicine according to Charak is to maintain the health of healthy person and relieve the suffering. The ancient
Indian physicians had a sound knowledge of Madhumeha. They described the clinical features and complications of Madhumeha vividly. Madhumeha is the subtype of Pramehah". Accord- 
ing to Sushrut Acharya all types of Prameha if not treated in time, ultimately leads to Madhumeha which is incurable. Whatever may be the fact, Madhumeha does have the fundamental characters viz polyuria and turbidity of urine (Prabhutavilamutrata). Due to resemblance of the features of Madhumeha with that of DM explained in modern medicine, it is correlated with DM. According to WHO approximately 220 million people worldwide have type 2 diabetes mellitus. The exact cause of type 2 diabetes is still not clear. Since the 17 th century, it has been suggested that emotional stress plays a role in the etiology of type 2 diabetes mellitus. It is widely recognized that stress may have negative effects on health and that patients with type 2 diabetes may be at an increased risk. Changing lifestyle are showing upward trend in India. Sushruth and Charak emphasized the importance of diet and exercise in the management of diabetes. Yoga is an ancient heritage of our culture. Several older books make a mention of the usefulness of yoga in the treatment of certain diseases and preservation of health in normal individuals. Apart from its spiritual philosophy, yoga has been utilized as a therapeutic tool to achieve positive health and cure disease. This concept is promoted in Hathayoga Yogic practices strengthen and increase the tone of weak muscle, lower metabolic states, lowers level of the stress hormones, change in the activity of the autonomous nervous system and increase in insulin secretion. So, the present study on the role of Yogaabhyas as a lifestyle modification in Madhumeha

Materials and Methods- All the available authentic books in the yogic literature have been referred for the specific materials. Related modern books, internet websites, magazines articles etc. have been used as literary materials

\section{Conceptual View-}

Sedentary habits and unhealthy dietary patterns are the major risk factors for the development of various lifestyle disorders, including diabetes. Lack of physical activity was found to increase the risk of diabetes. Type 2diabetes is a common lifestyle disorder caused by insulin resistance with relative or absolute insulin deficiency, resulting in chronic hyperglycaemia and various cardiovascular complications. Globally, according to the International Diabetes Federation diabetes atlas (eighth edition, 2019), in 2019 there were roughly 463 million people with diabetes, a figure that is projected to increase to 629 million by 2045 . Yoga has been practised since ancient times, yoga as therapy is still a relatively new and emerging trend in the healthcare field. This has facilitated the practical application of yoga in various diseases, and it is now being recognized worldwide as a clinically viable treatment. Traditionally a mind-body practice with the ultimate goal of spiritual enlightenment, yoga is a science of health management, rather than a therapy for treating specific diseases. Therefore, in studies incorporated the following asanas Dhanurasana, Ardhamatsayendrasana, Bhujangasana, Naukasana, Halasana, Vajrasa$n a$ and Pachimotanasana along with pranayam. Selected 8 asanas which could be performed by all age groups, performed yogic practices for 45 minutes each day followed by relaxation practices i.e. Shavasana and Makrasana. 


\section{Mechanism of Asana in Diabetes}

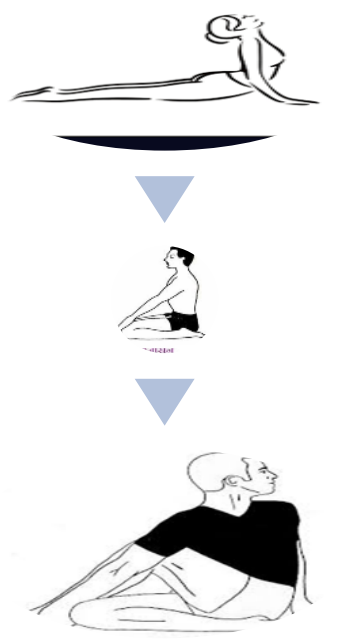

Asanas emphasize the relationship of body, mind, and awareness, focusing on the synchronization of breathing and movement. They involve stretching/twisting movements and relaxation. Seated postures improve pancreatic function. Asanas with forward bends massage and pressurize the pancreas and stimulate the secretion of insulin. Twisting poses squeeze the intestines and massage them to prevent the stagnation of colonic contents. For therapeutic benefits, the poses need to be maintained for approximately 30 seconds to 1 minute. Diabetes is a chronic metabolic disease that adversely affects quality of life. Psychological stress and negative mood have a bidirectional effect in the control of diabetes. Stress increases the risk and severity of diabetes by stimulating the hypothalamic-pituitaryadrenal (HPA) and sympathetic axes and parasympathetic. Chronic activation of the HPA axis is associated with poor control of diabetes and complications such as diabetic neuropathy. An increased level of inflammatory cytokines results in insulin resistance in patients with type 2 diabetes. Chronic psychological stress can result in insulin resistance, hypertension, and an increased risk of cardiovascular events. Yoga reduces oxidative stress; Yoga therapy increases the number of insulin receptors and increases the proportion of receptor binding in patients with diabetes. The various health benefits of yoga therapy are related to changes in the level of various hormones and neurotransmitters, joy and euphoria during yoga therapy are due to an increase in $\beta$-endorphin, serotonin, and dopamine levels, im- provements in arousal are due to increased argininevasopressin levels, which reduce the gamma-amino butyric acid (GABA)-ergic inhibition of the supraoptic area of the hypothalamus, its calming effect is due to melatonin, the ecstatic and blissful feelings that arise during yoga are due to lateral hypothalamic stimulation, and the decrease in spatial orientation and out-of-body experiences during meditation are due to decreased levels of GABA and increased levels of $\mathrm{N}$-acetylaspartylglutamate and 5methoxydimethyl tryptamine (from pineal enzymes). It improves insulin kinetics by reducing fasting insulin levels, shifting the peak insulin level to the left, and by normalising the insulin-to-glucose ratio. It also reduces levels of free fatty acids, indirectly indicating improved insulin sensitivity or reduced insulin resistance. Yoga practice improves flexibility, muscle strength, blood circulation, and oxygen uptake. Abdominal stretching during yoga exercises is believed to result in the regeneration of pancreatic cells. The various postures during yoga practice help to improve the sensitivity of $\beta$-cells to glucose, thereby improving insulin secretion, and increase the blood supply to the muscle and muscle relaxation, thereby improving glucose uptake. Improvements in hormonal homeostasis also improve glycaemia control in people with diabetes mellitus. Yoga therapy also results in immunomodulation by reducing proinflammatory responses and improving immune function. Yoga reduces levels of triglycerides, low density lipoprotein cholesterol, and free fatty acids, and improves high density lipoprotein 
cholesterol levels. Yoga asana also modulate gene expression and increase muscle activity, strength, endurance, flexibility, and balance, resulting in favourable effects on body weight, adiposity, dyslipidaemia, and insulin resistance.

Pranayama (yogic breathing)- Pranayama is controlled or regulated yogic breathing practice. The slow breathing technique regulates the heart rate and its variability. The vibrations created in Bhramari Prayanama (humming bee breath) have a soothing and calming effect on the mind and could play a vital role in improving mental and physical health. Right nostril breathing is believed to have a sympathetic stimulating effect and may be recommended in people with diabetes. Bhastrika Pranayama (bellow-breathing) is a powerful and energetic pranayama referred to as "the breath of fire." It helps in the regulation of the pineal, pituitary, and adrenal glands, which play an important role in the regulation of metabolism.

\section{CONCLUSION}

Yoga postures had a positive effect on glucose utilization and fat redistribution in individuals with type 2 diabetes. In diabetes, pancreatic cells rejuvenated, and pancreatic $\beta$-cell sensitivity increased by the alternating abdominal contractions and relaxations involved in yoga practice. Improved blood supply to muscles enhance insulin receptor expression in the muscles, causing increased glucose uptake. The regular practice of yoga reduces the risk of diabetesrelated complications. Cardiac autonomic dysfunction is believed to be a cause of sudden death in patients with diabetes mellitus. The regular yoga practice improved cardiac autonomic function independently of glycaemic control and reduced the risk of cardiovascular events. Yoga therapy also stabilizes the coagulation profile, thereby improving nerve conduction and cognitive function in patients with diabetes.

The ease of use, safety, and multiple psychological benefits of yoga have led it to be more widely accepted in society, and it can now be considered a low-cost intervention to control various lifestyle disorders, including diabetes.

\section{REFERENCES}

1. Gheranda samhita, by Swami Digambarji and Dr M.L. Gharote, published by Shri O P Tiwari, third edition 2014, p32

2. Swami Satyananda Saraswati, Asan pranayama mudra bandha, Edition first 1969, second edition 1996, fourth edition 2008, Publisher and distributor yoga publication trust. Gangadarshion Munger, Biharindia printed at Thomson press limited new Delhi,110008. Pgno 102,350, p 128

3. Preventive and social Medicine. K Park ,2013 edition Banarasi das Bhanot Publisher. edition 2013, p 537

4. Charak Samhita I \& II Part, Pt. Kashinath Shastri, Dr. G.N. Chaturvedi, Reprinted 1998, Chaukhamba Visvabharti Varanasi p 455

5. Sushruta Samhita, Ayurveda Tatvasandipika Hindi Commentary, by Kaviraja Ambika Datta Shastri.17th ed.2003, Su.Sharira. 4/30, Varanasi: Chaukhambha Sanskrita Sansthana.p568

6. Pancham Singh, Editors, The Hathayogpradipika, Chaukhambha Sanskrit Pratisthan, Delhi, Edition 2011 2/ 22, P. 27

7. S. P. Nimbalkar, Editors, Pranayam - an effective means to mental health, Yoga Vidya Niketan, Mumbai, Edition 2009, P. 135

8. Rai bahadur Srisa Chandra Vasu, Editors, The Gheranda Smahita, Chaukhambha Vidyabhawan, Varanasi, edition reprint-2014, 1/55-56, P. 20

9. S. P. Nimbalkar, Editors, Pranayam - an effective means to mental health, Yoga Vidya Niketan, Mumbai, Edition 2009, P. 138

10. Sadashiv nimbalkar, Editors, Yoga for health and peace, Yoga Vidya Niketan, Mumbai, $8^{\text {th }}$ edition 2012, P. 48

11. S. P. Nimbalkar, Editors, Pranayam - an effective means to mental health, Yoga Vidya Niketan, Mumbai, Edition 2009, P. 135

\section{Source of Support: Nil Conflict of Interest: None Declared}

How to cite this URL: Bansode Sheetal: Efficacy of Yogaabhyas in the Mangement Of Madhumeha w.s.r to Niddm (Type 2). International Ayurvedic Medical Journal \{online\} 2021 \{cited January, 2021\} Available from: http://www.iamj.in/posts/images/upload/239 242.pdf 